Journal of Nonformal Education and Community Empowerment

Volume 1 (1): 87-101, Juni 2017

Available athttp://journal.unnes.ac.id/sju/index.php/jnfc

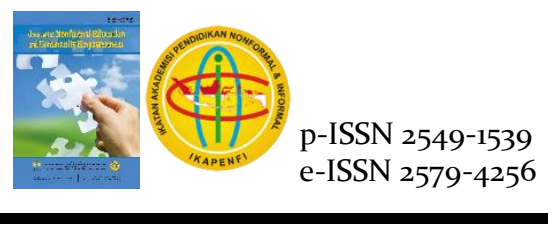

\title{
Pengembangan Kewirausahaan Berbasis Potensi Lokal melalui Pemberdayaan Masyarakat
}

\author{
Abdul Malik ${ }^{\bowtie}$, Sungkowo Edy Mulyono
}

Jurusan Pendidikan Luar Sekolah, FIP Universitas Negeri Semarang

\begin{tabular}{l}
\hline Info Artikel \\
\hline Sejarah Artikel: \\
Diterima April 2017 \\
Disetujui Mei 2017 \\
Dipublikasikan Juni 2017 \\
\hline Keywords: \\
local potential; \\
entrepreneurship; community \\
empowerment
\end{tabular}

\begin{abstract}
Abstrak
Tujuan penelitian ini adalah mendeskripsikan pengembangan kewirausahaan berbasis potensi lokal melalui pemberdayaan masyarakat yang terdiri dari beberapa tahapan diantaranya pelatihan, proses produksi dan pemasaran serta kendala yang dialami. Penelitian ini menggunakan pendekatan kualitatif dengan menggunakan data primer yang dikumpulkan melalui wawancara, observasi, dan dokumentasi. Subyek penelitian terdiri warga belajar Paket C di PKBM Cipta Karya Kecamatan Prambanan Kabupaten Klaten dan sebagai informan adalah tokoh masyarakat. Keabsahan data menggunakan triangulasi sumber, metode dan teori. Analisis data sebagaimana model interaktif mencakup pengumpulan data, reduksi, penyajian dan penarikan kesimpulan. Penelitian ini menghasilkan program pemberdayaan dalam proses pengembangannya dilakukannya pelatihan pembuatan jam tangan dari kayu. Produksi dilakukan oleh warga belajar Kejar Paket B dan C setelah selesai pembelajaran kejar paket. Pemasaran dilakukan melalui promosi di berbagai media dan pangsa pasarnya baik dalam maupun luar negeri. Kendala yang dialami minimnya mesin produksi yang bersumber dari minimnya modal dan terbatasnya jam kerja warga belajar.
\end{abstract}

\begin{abstract}
The purpose of this study is to describe the development of entrepreneurship based on local potential through community empowerment consisting of several stages including training, production and marketing processes and constraints experienced. This study used a qualitative approach using primary data collected through interviews, observation, and documentation. The subjects of the study consisted of citizens learning Package $C$ in PKBM Cipta Karya District of Prambanan Klaten and as informants were community leaders. The validity of data using triangulation of sources, methods and theories. Data analysis as an interactive model includes data collection, reduction, presentation and conclusion. This research resulted in empowerment program in the process of developing the training of watch manufacture from wood. The production was done by the residents learning Kejar Paket $B$ and $C$ after completion of the packet learning process. Marketing is done through promotion in various media and market share both domestic and abroad. Constraints experienced by the lack of production machinery that comes from the lack of capital and limited hours of work citizens learn.
\end{abstract}

(C) 2017 PLS FIP UNNES

\footnotetext{
${ }^{\square}$ Alamat korespondensi:

E-mail: abdul.malik@mail.unnes.ac.id
} 


\section{PENDAHULUAN}

Program penanggulangan kemiskinan dewasa ini lebih mengandalkan kreativitas dan prakarsa masyarakat di daerah. Pemerintah pusat yang sebelumnya sangat dominan dalam program penanggulangan kemiskinan, kini harus berubah menjadi sekedar pemberi fasilitas dan pendampingan-pendampingan bagi program-program penanggulangan kemiskinan. Sehubungan dengan hal tersebut, langkah awal upaya penanggulangan kemiskinan di daerah dilakukan analisis situasi untuk menemukan potensi daerah yang dapat dikembangkan sebagai sarana atau alat pemberdayaan masyarakat. Hasil analisis situasi menunjukkan penyebab kemiskinan adalah banyaknya pengangguran usia produktif karena mereka tidak memiliki pendidikan dan keterampilan yang memadai untuk mengantarkan mereka kepada suatu pekerjaan yang memiliki daya jual tinggi. Situasi tersebut berkaitan dengan latar belakang kehidupan warga masyarakat miskin yang mengalami ketidakberdayaan di bidang ekonomi. Maka sudah dapat dipastikan mereka tidak dapat menjangkau pendidikan formal maupun nonformal (kursus) yang mampu membekali keterampilan untuk mencari penghasilan yang layak. Mahalnya biaya pendidikan baik formal maupun nonformal mengakibatkan warga masyarakat produktif tidak mampu mengikutinya. Dalam suatu usaha untuk mendefinisikan peranan Pendidikan Nonformal (PNF) dalam mendukung pembangunan, telah dikaji pembangunan dan PNF yang saling berkaitan. Coombs, Prosser, \& Ahmed (1973) menyampaikan bahwa PNF sebagai strategi bagi pembangunan perdesaan. (Rifai, 2008:33) menyampaikan juga bahwa "Melalui PNF dapat mentransformasikan dan memperkuat pendidikan persekolahan untuk membantu memenuhi kebutuhan belajar minimum pada esensi bagi jutaan anak dan pemuda yang kurang berpendidikan dan membantu mempercepat pembangunan sosial dan ekonomi". Pembangunan yang terjadi di perdesaan, dapat meningkatkan produksi dan pendapatan, meningkatnya tenaga kerja, kesehatan, nutrisi dan perumahan yang lebih baik bagi semua penduduk perdesaan, memperluas kesempatan pendidikan bagi semua orang, memperkuat makna kerjasama dan pengaturan diri masyarakat lokal, mengatasi kemiskinan serta meningkatkan keadilan sosial.

Karena ketidakmampuan yang terjadi di masyarakat, maka diperlukan terobosan dan pendekatan baru yang salah satu diantaranya adalah pengembangan kewirausahaan untuk meningkatkan ekonomi masyarakat miskin melalui pemberdayaan. Pengembangan kewirausahaan masyarakat diharapkan menjadi terobosan baru agar dapat mempercepat pencapaian tumbuhnya wirausaha-wirausaha yang mandiri yang memiliki karakter inovatif, tangguh dan berwawasan global. Hadiyanti (2006:38) mengungkap ada beberapa faktor internal yang menghambat pemberdayaan antara lain, kurang bisa untuk saling mempercayai, kurang daya inovasi/kreativitas, mudah pasrah/ menyerah/putus asa, aspirasi dan cita-cita rendah, tidak mampu menunda menikmati hasil kerja, wawasan waktu yang sempit, familisme, sangat tergantung pada bantuan pemerintah, sangat terikat pada tempat kediamannya dan tidak mampu/tidak bersedia menempatkan diri sebagai orang lain. Pada sisi lain, Esmailzade (2013) mengutarakan bahwa yang menjadi faktor yang mempengaruhi pariwisata pembangunan perdesaan adalah kondisi dasar (basement), manajemen, perencanaan, penelitian dan penelitian.

Menciptakan wirausaha (entrepreneur) yang berkarakter inovatif, tangguh dan berwawasan global tidaklah mudah, karena diperlukan prasyarat-prasyarat tertentu, diantaranya adalah mampu menatap masa depan dengan penuh optimis, selalu berusaha menjadi yang terdepan dalam setiap perubahan, pantang menyerah dan mengikuti trend perkembangan dunia. Harper (1991) menyatakan, untuk suksesnya permulaan usaha memerlukan kemampuan membaca peluang yang tepat, memiliki keahlian dan kemampuan pada bidang yang akan ditekuni, melakukan pendekatan yang benar dalam menjalankan usaha, dan memiliki dana yang cukup untuk 
memulai dan mengoperasikan usaha. Teori kebutuhan yang dikemukakan Mc Clleland (Idris, 2003) yang salah satunya dikenal dengan need for achievement atau " $n$ Ach", menyatakan beberapa orang yang berjiwa entrepreneur memiliki kebutuhan untuk berprestasi demikian kuat sehingga ia lebih termotivasi dibandingkan upaya mencapai keuntungan. Untuk memaksimalkan kepuasannya, seseorang dengan kebutuhan berprestasi yang tinggi, cenderung menetapkan tujuan mereka sebagai tantangan yang hendak dicapai. Individu yang termotivasi oleh keinginan berprestasi yang tinggi, cenderung melakukan pekerjaan yang berisiko dengan perhitungan, namun individu yang memiliki keinginan rendah untuk berprestasi umumnya menghindari tantangan, tanggung jawab, dan risiko.

Kecenderungan masyarakat dalam berwirausaha adalah mencari cara-cara yang tidak memiliki tantangan dan tidak berisiko. Cara seperti ini, biasanya dilakukan oleh entrepreneur pemula dengan modal dan pengalaman terbatas. Hal ini dapat dimaklumi, karena entrepreneur pemula dengan modal terbatas masih rentan dengan risiko yang dialami. Sekali ia mencoba berusaha lalu gagal, akan selamanya terpuruk tidak akan bangun untuk selamanya, dan bahkan ia akan menggadaikan segala yang dimilikinya untuk membayar risiko yang diembannya. Untuk mengembangkan kewirausahaan berbasis potensi lokal diperlukan strategi pengembangan kewirausahaan melalui pemberdayaan masyarakat, agar mudah memahami dan memanfaatkan potensi yang dimiliki. Orientasi pemberdayaan itu sendiri adalah bertumpu adanya kemandirian. Adisasmita (2006:45) dalam pembangunan yakni "Masyarakat memiliki peran utama yang menentukan pilihanpilihannya terhadap kebijakan pembangunan sesuai dengan kebutuhan dan aspirasi masyarakat".

Kemandirian menyangkut erat terhadap kemampuan. Kemandirian berarti juga mampu membuat keputusan yang tepat dalam menghadapi berbagai persoalan yang menyangkut pribadinya dan masyarakatnya.
Oleh karenanya, melalui pembelajaran kewirausahaan yang lebih tepatnya pendidikan kewirausahaan warga belajar atau masyarakat akan dapat memiliki kemampuan. Seperti yang disampaikan oleh Suryono \& Sumarno (2013:37), "Kemampuan hanya dapat dipersiapkan melalui pendidikan, pelatihan, atau penyuluhan, dengan berbagai metode yang cocok dengan kondisi warga belajar dan konteks masyarakatnya". Uemura (2005) menyatakan keberhasilan pembangunan jelas mengartikulasikan pentingnya pembangunan dari dalam. Pendekatan yang mengedepankan kemandirian kelompok lokal sendiri bukan dari luar. Keberhasilan juga terletak pada "tradisi" dan sepenuhnya memanfaatkan sumber daya lokal sebagai bahan pembangunan dari dalam. Hal ini juga menggarisbawahi kebutuhan untuk memikirkan kembali cara di mana bantuan seharusnya tidak memaksa masyarakat lokal untuk berkembang menjadi jaket yang dibuat oleh pihak luar, sebaliknya harus memaksimalkan dinamika dalam kemandirian masyarakat setempat dengan mempercayainya sebagai mitra.

Terkait dengan kewirausahaan, Kaswan \& Akhyadi (2015:8) menegaskan, "Ada dua hal esensial dalam masyarakat wirausaha: inovasi dan kewirausahaan, yang merupakan aktivitas yang menopang kehidupan yang terpadu". Demikian halnya Suryono \& Sumarno (2013) menyangkut kewirausahaan setidaknya terdapat tiga komponen, yaitu pembelajaran kewirausahaan, adanya inkubator wirausaha dan sentra kewirausahaan. Aktivitas kewirausahaan umumnya tidak terselenggara pada lingkup pendidikan, apalagi pendidikan formal. Akan tetapi, aktivitas kewirausahaan terbentuk atas dasar pondasi melalui pendidikan. Begitu pula spektrum kewirausahaan berbasis pada masyarakat. Demikian halnya, jiwa wirausaha dibentuk melalui aktivitas pendidikan. Dengan adanya penelitian ini, merespon pada kondisi-kondisi tersebut.

Pusat Kegiatan Belajar Masyarakat (PKBM) yang merupakan lembaga penyelenggara pendidikan nonformal telah menyelenggarakan banyak program. PKBM 
merupakan lembaga pendidikan yang sangat dekat keberadaanya dengan masyarakat, maka disebut sebagai pusat kegiatan belajar di masyarakat. Apapun aktivitasnya, proses belajar dapat dilakukan di PKBM. Secara tempat penyelenggaraannya, PKBM dapat mencakup wilayah desa hingga kecamatan, atau kata lain setiap desa/kecamatan dapat didirikan PKBM. Hal ini berbeda dengan Sanggar Kegiatan Belajar (SKB) meskipun sama-sama bergerak di lingkup pendidikan nonformal, SKB hanya terdapat di tingkat kabupaten/kota serta pengelolaanya pun dipegang oleh pemerintah, sedangkan PKBM bersifar perorangan. PKBM dan SKB juga berbeda lagi dengan aktivitas pendidikan yang dikelola pemerintah yang diselenggarakan di lingkup pendidikan formal, seperti di SD, SMP, SMA bahkan perguruan tinggi. Yang pasti disini ingin menekankan bahwa PKBM adalah sebagai learning center-nya masyarakat. Sebagaimana yang diungkap hasil penelitiannya Raharjo, Suminar, \& Muarifuddin (2016), tiga peran PKBM sebagai wadah pusat pembelajaran bagi masyarakat yaitu pusat informasi, tempat masyarakat belajar, dan terselenggaranya pendidikan dan pelatihan keterampilan. Dari ketiga peran kunci tersebut, membentuk adanya kemandirian warga masyarakat. Agossou (2000:15) berpendapat, "Organizations including service agencies, NGOs and rural development organizations are using the participatory methods and helping communities develop capacity to undertake development activities". Banyak organisasi termasuk lembaga pelayanan, LSM dan organisasi pembangunan perdesaan yang menggunakan metode partisipatif dan masyarakat merasa terbantu dalam mengembangkan kapasitas untuk melakukan kegiatan pembangunan. Begitu pula pendapat Dirdjojuwono (2015:15), "Membangun perdesaan identik dengan modernisasi desa, yaitu proses mengubah kodisi sosial-ekonomi masyarakat desa lebih mendekati kondisi sosial-ekonomi masyarakat kota". Kemandirian dan modernisasi desa merupakan konsep utama penyelenggaraan desa wisata. Hal ini tentunya berdasarkan atas latar belakang atau masalahmasalah yang ada di desa. Pembentukan suatu desa menjadi desa wisata banyak bermula dari adanya pengembangan potensi lokal/kearifan lokal. Potensi tersebut mampu dikembangkan menjadi suatu unggulan tersendiri dari sebuah desa.

Selain program Pendidikan Anak Usia Dini (PAUD), Keaksaraan, Kesetaraan, di PKBM juga terdapat berbagai program yang tujuan dasarnya adalah mengatasi berbagai masalah yang terjadi di masyarakat. Oleh karenanya program seperti pelatihan, kursus, penyuluhan, pendampingan, Kelompok Belajar Usaha (KBU), magang serta program lain terdapat di PKBM. Adapun kegiatan kewirausahaan dapat diintegrasikan dalam program tersebut yang relevan. Seperti halnya kewirausahaan terintegrasi pada program keaksaraan, kesetaraan (kejar paket), bahkan kelompok belajar usaha. Sedangkan di program kesetaraan terdapat adanya Kejar Paket A (setara SD), Kejar Paket B (setara SMP), dan Kejar Paket C (setara SMA).

Berdasarkan uraian yang telah dikemukakan, penelitian ini berfokus pada pengembangan kewirausahaan berbasis potensi lokal melalui pemberdayaan masyarakat yang terdiri dari beberapa tahapan diantaranya pelatihan, proses produksi dan pemasaran serta kendala yang dialami. Lokasi penelitian berada di PKBM Cipta Karya yang berlokasi di Dukuh Gilangsari Desa Pareng Kecamatan Prambanan Kabupaten Klaten Provinsi Jawa Tengah yang juga menyelenggarakan program kesetaraan kejar paket A, B dan C. Lokasi diambil dengan mempertimbangkan potensi lokal yang telah ada, diantaranya kondisi geografis masih hutan, serta dekat dengan tempat wisata Candi Prambanan. Oleh karenanya, dapat menarik pengunjung baik dalam maupun mancanegara untuk bisa mengakses hasil dari pengembangan kewirausahaan yang terselenggara. Seperti yang ditegaskan oleh Kavaliku (2005:12), "The possibilities of regional unity, but much about the capacity of local cultures everywhere to seize the opportunities and the wealth provided by the global system for whatever good things make up the local conception of human existence". Suatu Daerah memungkinkan banyaknya kapasitas budaya 
lokal yang ada di mana-mana yang mampu menjadi peluang dan kekayaan yang disediakan oleh sistem global sebagai bagian dalam meningkatkan eksistensi manusia untuk membuat konsep lokal. Seperti yang ditekankan juga oleh Susilo \& Soeroso (2014) faktor penentu pelestarian kebudayaan adalah dengan menjaga suasana kekerabatan yang tetap kondusif, menciptakan kenyamanan kehidupan pergaulan di antara warga dan menjaga bahkan meningkatkan rasa percaya di antara anggota masyarakat.

\section{METODE}

Penelitian ini menggunakan pendekatan diskriptif kualitatif. Metode diskriptif kualitatif dapat diartikan sebagai prosedur pemecahan masalah yang diselidiki dengan menggambarkan atau melukiskan keadaan subjek atau objek penelitian (orang, lembaga dan masyarakat) pada saat sekarang berdasarkan fakta-fakta yang nampak dan sebagaimana adanya (Nawawi, 2005). Penelitian ini bermaksud untuk memahami fenomena tentang apa yang dialami oleh subjek secara holistik dan dengan cara deskripsi dalam bentuk kata-kata dan bahasa, dan dengan memanfaatkan berbagai metode ilmiah. Dasar penelitian ini diharapkan mampu memberikan gambaran yang jelas, terinci dan ilmiah.

Penelitian dilakukan di PKBM Cipta Karya yang berlokasi di Dukuh Gilangsari Desa Pareng Kecamatan Prambanan Kabupaten Klaten Provinsi Jawa Tengah. Lokasi ini dipilih dengan mempertimbangkan beberapa alasan, diantaranya adalah terdapat masyarakat miskin yang membutuhkan kewirausahaan usaha kecil melalui pemberdayaan, selain itu memiliki potensi lokal berupa hutan yang dapat dipergunakan untuk kewirausahaan.

Populasi penelitian ini adalah warga belajar paket $\mathrm{B}$ dan $\mathrm{C}$ berjumlah 80 orang yang berada di PKBM Cipta Karya. Adapun sampel/responden dalam penelitian ini meliputi 5 warga belajar 2 tutor dan 2 informan yaitu 1 pengelola PKBM dan 1 tokoh masyarakat.

"Fokus penelitian pada dasarnya merupakan masalah yang bersumber pada pengalaman peneliti melalui pengetahuan yang diperoleh melalui kepentingan ilmiah ataupun kepustakaan lainnya" (Moleong, 2001:65). Fokus penelitian mencakup profil PKBM Cipta Karya Kecamatan Prambanan Kabupaten Klaten, strategi pengembangan kewirausahaan usaha kecil melalui pemberdayaan masyarakat melalui PKBM Cipta Karya, dan dampak kewirausahaan terhadap status sosial ekonomi masyarakat Kecamatan Prambanan Kabupaten Klaten.

Data primer diperoleh dari observasi atau pengamatan langsung di lapangan dan responden atau informan, yaitu mereka yang terlibat secara langsung dalam kegiatan. Aspekaspek yang diobservasi antara lain peningkatan literasi dan usaha mandiri. Data skunder berupa data yang bersumber pada dokumen yang berupa foto, catatan, rekaman, gambar, maupun sumber data lain dari jurnal, buku, dan hasil penelitian terdahulu yang relevan.

Pengumpulan data menggunakan metode wawancara mendalam (in depth interview), observasi/pengamatan lapangan, dan dokumentasi. Wawancara dilakukan antara peneliti dengan responden atau informan secara mendalam. Responden atau Informan dalam penelitian ini adalah warga belajar Kejar Paket B dan C di PKBM Cipta KaryaKecamatan Prambanan Kabupaten Klaten. Observasi dilakukan untuk memperoleh gambaran yang utuh, jelas, dan mendalam dari subjek yang diteliti. Observasi juga dilakukan jika belum banyak keterangan yang dimiliki oleh peneliti tentang masalah yang diteliti, yaitu profil dan pengembangan kewirausahaan masyarakat. Adapun hal-hal yang diamati dalam penelitian ini adalah masyarakat miskin yang membutuhkan kewirausahaan usaha kecil. Data skunder berasal dari data masyarakat miskin, dan perilaku masyarakat miskin.Dalam penelitian ini ada beberapa dokumen atau arsip yang sangat dibutuhkan sehingga harus dikumpulkan. Adapun hal-hal yang menjadi bahan dokumentasi dalam penelitian ini antara lain: daftar hadir peserta, kartu hasil studi, dan dokumen-dokumen lain yang relevan dengan tujuan penelitian. 
Data dalam penelitian ini dianalisis secara kualitatif melalui tahapan-tahapan yang sesuai dengan prosedur yang telah ditentukan, yaitu pengumpulan data, reduksi data, display/penyajian data, dan verifikasi/penarikan kesimpulan yang telah populer dikenal dengan istilah model interaktif oleh Miles \& Hubberman.Reduksi data merupakan proses pemilihan, penyusunan, pemusatan perhatian pada penyederhanaan, pengabstrakan, dan transformasi data kasar yang muncul dari wawancara dan dokumentasi. Dalam penelitian ini data yang diperoleh dikumpulkan terlebih dahulu dalam bentuk catatan. Data hasil pengamatan atau observasi yang dilakukan kemudian dibuat deskripsi dan diberikan refleksi atau catatan peneliti untuk memudahkan peneliti dalam pengelompokan dan analisis.Data yang telah direduksi kemudian ditampilkan atau disajikan dalam deskripsi yang sistematis sesuai dengan tujuan penelitian ini. Penyajian data ini bertujuan agar data yang telah dikumpulkan dan direduksi dapat dikomukasikan secara mudah sehingga dapat dipahami. Penarikan kesimpulan dan analisis data dilakukan dengan mencari pola, tema, hubungan, dan persamaan hal-hal yang terjadi. Data yang masih kabur dan diragukan dipertanyakan kembali sehingga diperoleh kesimpulan yang lebih mendalam. Langkah berikutnya adalah dilakukan cek silang atau triangulasi yang dilakukan kepada subjek penelitian. Tahapan analisis data secara jelas sesuai skema pada gambar 1 :

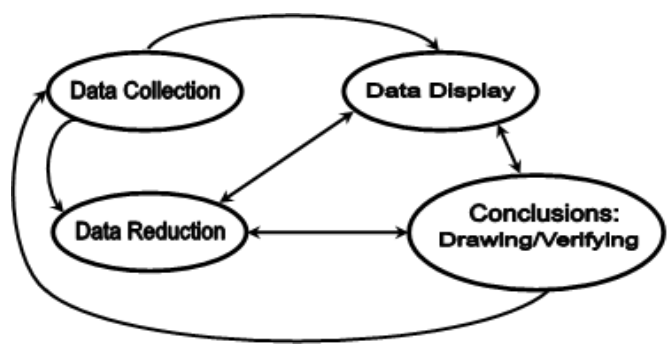

Gambar 1.Komponen Analisis Data Model Interaktif (Sumber: Miles \& Hubberman, 1994:12)

Agar data yang telah dianalisis dapat dipertanggungjawabkan kebenaran dan keabsahannya, maka langkah yang dilakukan adalah Member Check, Peerdebriefing, dan Audit Trail.Member Check adalah menanyakan kembali pernyataan yang telah dirangkum dalam pemahaman peneliti untuk memastikan kebenaran makna yang dibuat sampai diperoleh data yang betul-betul mantap, sehingga merupakan suatu siklus yang tiada henti. Peerdebriefing adalah membicarakan dengan orang lain yang mempunyai pengetahuan tentang pokok-pokok yang diteliti. Audit Trail adalah yaitu menguji keakuratan data agar data yang dianalisis betul-betul dapat dipertanggungjawabkan kebenarannya. Adapun penentuan keabsahan data dalam penelitian ini dilakukan dengan cara memeriksa data yang telah diperoleh. Pelaksanaan teknis pemeriksaan didasarkan atas sejumlah kriteria tertentu, antara lain derajat kepercayaan, keteralihan, kebergantungan dan kepastian.

\section{HASIL DAN PEMBAHASAN Profil PKBM Cipta Karya}

Kabupaten Klaten secara geografis memiliki wilayah yang sebagian besar terdiri dari hutan. Dimana hutan tersebut menghasilkan berbagai jenis kayu diantaranya kayu mahoni, sonokeling, dan jati. Hutan tersebut merupakan potensi lokal yang dimiliki kabupaten Klaten, selain potensi-potensi lain yang ada seperti pariwisata, pertanian, perkebunan. Dari berbagai kekayaan hutan yang dimiliki oleh kabupaten Klaten salah satunya dimanfaatkan untuk kewirausahaan berupa keterampilan jam tangan kayu. Adapun salah satu lembaga yang memanfaatkan hutan tersebut adalah lembaga pendidikan nonformal yang disebut dengan PKBM (Pusat Kegiatan Belajar Masyarakat). Salah satu PKBM yang ada di Kabupaten Klaten antara lain adalah PKBM Cipta Karya, yang berlokasi di Dukuh Gilangsari, Desa Pareng, Kecamatan Prambanan Kabupaten Klaten, Provinsi Jawa Tengah. PKBM Cipta Karya berdiri sejak tahun 2006 yang dikelola oleh saudara Wanto. Sejak berdiri tahun 2006 PKBM Cipta Karya telah menjalankan berbagai kegiatan, antara lain program-program pendidikan kesetaraan (kejar paket), keaksaraan fungsional (KF) serta 
program-program pelatihan. Adapun program pendidikan kesetaraan yang ada di PKBM adalah program Kelompok Belajar Paket A, B, dan C.

Program pemberdayaan masyarakat dimulai dari keaksaraan fungsional (KF) serta pelatihan-pelatihan dan sejak tahun 2008 dikembangkan kewirausahaan pembuatan jam tangan dari bahan kayu. Adapun bahan-bahan kayu didapatkan dari wilayah sekitar Kecamatan Prambanan Kabupaten Klaten. Jenis bahan kayu yang digunakan antara lain adalah sonokeling, mahoni, jati, dimana kayu-kayu tersebut berasal dari Kabupaten Klaten. Adapun tujuannya adalah mengoptimalkan potensi lokal yang dimiliki Kabupaten Klaten.

\section{Pengembangan Kewirausahaan Berbasis Potensi Lokal}

Kewirausahaan sangat dibutuhkan dalam membangun perekonomian bangsa. Dimana sebuah negara yang maju adalah memiliki entrepreneur minimal 2,5\% dari total penduduk. Untuk memacu perkembangan kewirausahaan di berbagai daerah sangat diharapkan adanya pengembangan-pengembangan baik yang dilakukan oleh lembaga pemerintah maupun lembaga swasta. Sebagaimana di Kabupaten Klaten sangat diharapkan adanya pengembangan kewirausahaan, mengingat Kabupaten Klaten memiliki sumberdaya alam yang cukup melimpah untuk pengembangan kewirausahaan. Potensi lokal yang dimiliki kabupaten Klaten antara lain adalah hutan kayu. Untuk mengembangkan hutan kayu, maka PKBM Cipta Karya melakukan terobosan baru yaitu melalui program pendidikan kesetaraan dengan menyelenggarakan pelatihan pembuatan jam tangan dari bahan kayu. Dalam pengembangan telah dilakukan inovasi dan kreativitas oleh PKBM, agar program kewirausahaan yang dijalankan mampu menerobos pangsa pasar. Adapun pengembangan kewirausahaan berbasis potensi lokal dilakukan dengan berbagai cara yaitu pelatihan, proses produksi dan pemasaran.

Program kewirausahaan melalui pelatihan pembuatan jam tangan kayu, yang dilaksanakan oleh PKBM Cipta Karya sudah berjalan sejak tahun 2006. Dimana program tersebut adalah sebuah program pelatihan yang diintegrasikan dengan pendidikan kesetaraan yaitu program paket B dan paket C. Berdasarkan hasil penelitian yang didapatkan, proses pembelajaran yang dilakukan sesuai dengan kurikulum pendidikan nonformal bahwa program kejar paket harus memasukkan kurikulum lokal, yang mana kurikulum lokal tersebut adalah kewirausahaan. Berdasarkan potensi lokal yang dimiliki kabupaten Klaten antara lain kekayaan hutan yang belum tersentuh untuk keterampilan. Maka PKBM Cipta Karya memasukkan kewirausahaan pelatihan keterampilan pembuatan jam tangan kayu, dimana warga belajar kejar paket selain mendapatkan materi secara umum juga mendapatkan materi khusus kewirausahaan yaitu pembuatan jam tangan kayu. Proses pembelajaran pelatihan dilaksanakan setelah materi pelajaran umum disampaikan. Hal ini seperti yang diungkap oleh Ketua PKBM Cipta Karya

"Ya pak potensi yang dimiliki kabupaten klaten diantaranya adalah hutan kayu, singga dalam pengembangan kewirausahaan kami menggunakan bahan dasar dari kayu, karena disini banyak kayu pak. Adapun proses pembelajaran pelatihan yang kami lakukan terintegrasi dengan pembelajaran pendidikan kesetaraan paket $B$ dan paket $C$ pak. Tujuan saya agar warga belajar paket juga memiliki keterampilan yang nantinya bisa untuk bekal hidup".

Proses pelatihan yang dilaksanakan di PKBM Cipta Karya di Kecamatan Prambanan Kabupaten Klaten bersamaan dengan pembelajaran paket B dan C. Dimana setiap pembelajaran diberikan materi kewirausahaan pembuatan jam tangan kayu. Adapun waktunya selama dua jam dan berlangsung selama satu semester. Bagi warga belajar yang sudah bisa diminta untuk memproduksi jam tangan kayu. Sebagaimana diungkapkan oleh $\mathrm{TH}$, warga belajar paket $\mathrm{B}$ 
"Nek menawi pembelajaran keterampilan buat jam kayu niku pak teng jam terakhir, mangke sakpune materi pelajaran nembe mulai praktek keterampilan pak, inggih niku ndamel jam saking kayu”.

Artinya " kalau pembelajaran keterampilan buat jam kayu itu pak di jam terakhir, nanti setelah materi pelajaran baru mulai praktek keterampilan pak, yaitu buat jam dari kayu".

Demikian juga yang dikatakan warga belajar kejar paket C yaitu WRD;

\begin{abstract}
"Waktu praktek kewirausahaan sekitar 2 jam pak, mulai jam 3 sampai jam 5 sore pak. Ya tahap-demi tahap pak, mulai memilih kayu yang baik sampau menggosok-gosok kayu, kemudian melubangi kayunya dan berlangsung selama tiga bulan. Ya itu karena kita belajarkan hanya tiga hari saja pak"
\end{abstract}

Setelah pelatihan diberikan, tahap pengembangan selanjutnya adalah proses produksi. Proses produksi jam tangan dilaksanakan pada saat selesainya pelajaran di PKBM Cipta Karya. Dalam proses produksi ini, disampaikan juga materi tentang teori yang berkisar $20 \%$ saja dan selebihnya adalah praktik pembuatan. Proses pembuatannya dimulai dari kayu dimasukkan ke dalam mesin untuk dihaluskan, kemudian dipotong-potong sesuai ukuran yang telah ditentukan. Selanjutnya dilubangi agar jarum perakit bisa dimasukkan, dan seterusnya dirangkai untuk menjadi sabuk jam. Warga belajar sangat antusias dalam memperdalam kewirausahaan karena warga belajar mendapatkan keterampilan dan sekaligus materi atau uang. Sampai dengan jam tangan kayu jadi warga belajar mendapat upah $\mathrm{Rp}$ 200.000,- (dua ratus ribu rupiah) dan itu bisa diselesaikan dalam waktu 3 sampai 4 hari. Sebagaimana disampaikan warga belajar bernama KMT, dia mengatakan:

"Proses pembelajaran keterampilan
kewirausahaan tidak lama kok

\author{
pak...paling-paling cuma 3 bulan kalau \\ warga belajar serius, tapi klo ada temen \\ yang kadang -kadang gak masuk \\ ya..sampai 4 bulan, mereka baru \\ terampil".
}

Upah warga belajar biasanya dalam satu bulan melebihi standar Upah Minimum Regional (UMR), yakni sekitar Rp 2.000.000,-. Ini berarti setiap warga belajar mampu memproduksi jam tangan kayu sebanyak 10 buah. Bagi warga belajar dengan penghasilan uang sebesar Rp 2 juta dalam satu bulan, dinilai sudah cukup untuk menghidupi dirinya. Sebagaimana dinyatakan oleh $\mathrm{TH}$ :

"Ya pak...kami dalam sebulan bisa memproduk sampai 10 biji jam, dan klo dihitung dengan uang nggih (ya) bisa sampai 2 juta inggih (ya) pak. Dan itu cukup untuk kehidupan saya ".

Sementara bagi warga belajar yang sudah lulus paket, mereka juga sebagian besar ikut bekerja di PKBM dengan memproduksi jam tangan kayu, dan penghasilan yang didapat bisa mencapai 2,5 juta sampai 3 juta. Dengan penghasilan tersebut mereka sudah merasa cukup untuk menghidupi keluarganya. Hal ini terungkap dari pernyataan RMT, alumni Paket $B$ yang bekerja di PKBM:

"Itu pak...alhamdulillah saya sekarang bekerja disini, ikut membuat jam tangan dari kayu, hasilnya lumayan kok pak, dalam satu bulan kami bisa mendapat uang sampai 2,5 juta dan kadang-kadang bisa 3 juta".

Tahapan berikutnya setelah proses produksi adalah pemasaran. Pemasaran hasil produksi mula-mula dijual oleh PKBM Cipta Karya kepada satu perusahaan saja, yaitu PT. VICO yang dimiliki oleh warga negara Amerika. Menurut pengakuannya, informasi tentang jam tangan kayu dia peroleh dari internet. Setelah berkunjung dan terjadi kesepakatan harga, dibuatlah surat perjanjian antara PKBM Cipta Karya dan PT. VICO. Adapun Harga per buahnya yaitu Rp 750.000,-. Dalam satu bulan PKBM 
Cipta Karya mampu memproduksi jam tangan kayu hingga 150 buah. Pihak PT.VICO mengambil jam tangan kayu setiap 3 bulan sekali. Sebagaimana diungkap oleh Suwanto (Pengelola PKBM):

"Untuk proses pemasaran produk kami ya.. awalnya kami didatangi oleh bule (orang sing) pak, yaitu warga negara Amerika dia melihat lihat produk kami katanya unik, kemudian dia tertarik dan melakukan kerjasama pak dengan PT. Vico yang dimiliki oleh warga Amerika tersebut. Dia bilang dapat informasi dari internet".

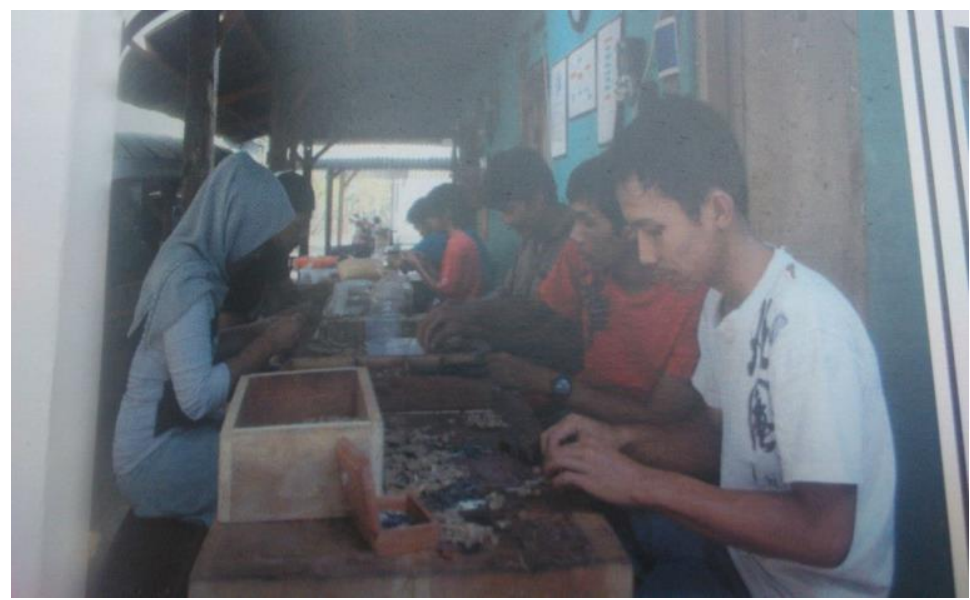

Gambar 1. Warga belajar sedang membuat jam tangan kayu

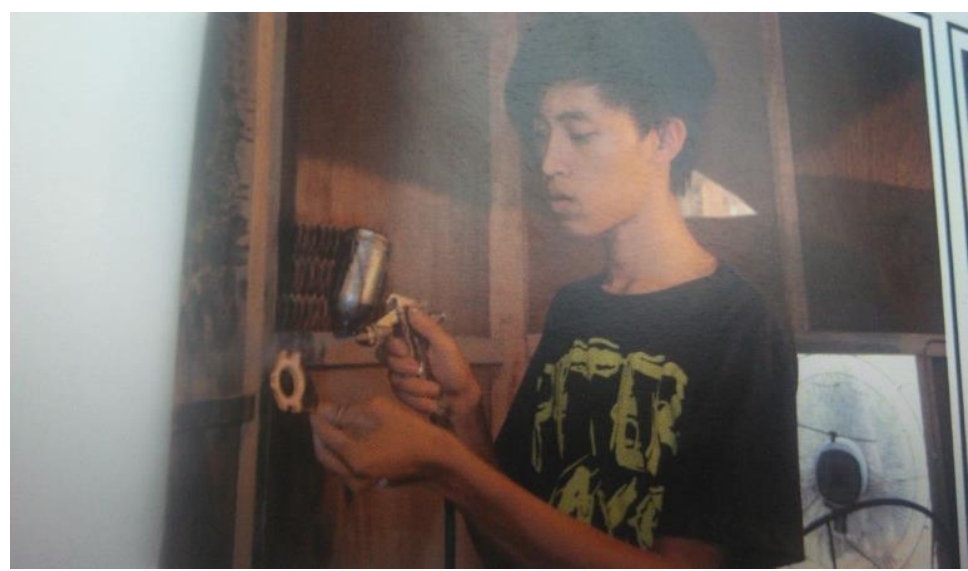

Gambar 2. Warga belajar sedang mengecat jam tangan kayu 


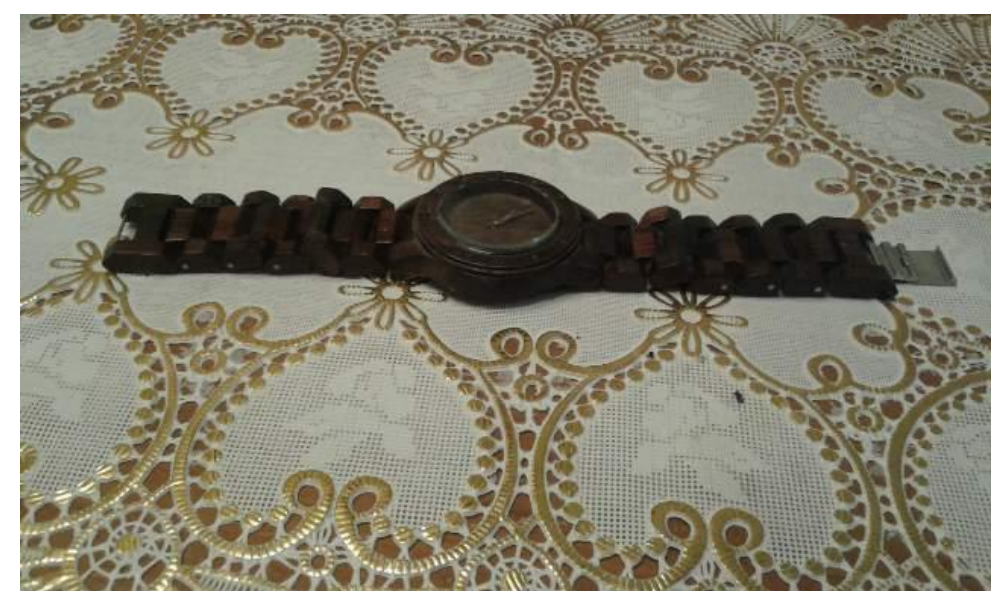

Gambar 3. Jam tangan kayu yang telah jadi

Tahapan berikutnya setelah proses produksi adalah pemasaran. Pemasaran hasil produksi mula-mula dijual oleh PKBM Cipta Karya kepada satu perusahaan saja, yaitu PT. VICO yang dimiliki oleh warga negara Amerika. Menurut pengakuannya, informasi tentang jam tangan kayu dia peroleh dari internet. Setelah berkunjung dan terjadi kesepakatan harga, dibuatlah surat perjanjian antara PKBM Cipta Karya dan PT. VICO. Adapun Harga per buahnya yaitu Rp 750.000,-. Dalam satu bulan PKBM Cipta Karya mampu memproduksi jam tangan kayu hingga 150 buah. Pihak PT.VICO mengambil jam tangan kayu setiap 3 bulan sekali. Sebagaimana diungkap oleh Suwanto (Pengelola PKBM):

"Untuk proses pemasaran produk kami ya.. awalnya kami didatangi oleh bule (orang sing) pak, yaitu warga negara Amerika dia melihat lihat produk kami katanya unik, kemudian dia tertarik dan melakukan kerjasama pak dengan PT. Vico yang dimiliki oleh warga Amerika tersebut. Dia bilang dapat informasi dari internet".

Seiring berjalannya waktu, PKBM Cipta Karya mengetahui bahwa harga jam tangan kayu di luar negeri (Amerika) ternyata cukup mahal, bisa menembus harga Rp 5 juta. Kemudian pada tahun 2012 PKBM Cipta Karya memutuskan hubungan kerja dengan PT. VICO agar tidak semua produk hanya dijual kepadanya akan tetapi dapat dijual secara umum. Hal ini seperti dinyatakan oleh Suwanto:

"Setelah saya hitung-hitung pak, dari hasil penjualan produksi pembuatan jam tangan kayu yang diabeli oleh orang Amerika itu pak...untung saya kecil, karena dihargai murah. Akhire kulo inggih (akhirnya saya ya) memutuskan hubungan dengan PT. Vico pak. Dan sekarang ini saya jual umum pak, biar untungnya PKBM meningkat".

Untuk model pemasaran yang dilakukan PKBM Cipta Karya sekarang ini adalah dengan melakukan sosialisasi ke berbagai perusahaan baik dalam maupun luar, dengan cara menggunakan fasilitas internet, brosur, serta media elektronik seperti Metro TV yang pernah meliput produksi jam kayu yang dibuat oleh PKBM Cipta Karya di Kabupaten Klaten.

Menurut Pinchot (Usman, 2010) kewirausahaan itu merupakan kemampuan untuk menginternalisasikan bakat, rekayasa, dan peluang yang ada. Sementara, wirausaha adalah orang yang berani mengambil risiko dan risiko tersebut telah diperhitungkan seoptimal mungkin, inovatif, kreatif, pantang menyerah, dan mampu mensiasati peluang secara tepat. (Kemendiknas, 2010) menyampaikan 
kewirausahaan adalah suatu sikap, jiwa, dan kemampuan untuk menciptakan suatu yang baru yang sangat bernilai dan berguna, baik bagi dirinya sendiri dan orang lain. Kewirausahaan ini merupakan sikap mental dan jiwa yang selalu aktif dan kreatif, berdaya, bercipta, berkarya, dan berusaha dalam rangka meningkatkan pendapatan atas kegiatan usahanya. Sementara wirausaha adalah orang yang terampil memanfaatkan peluang dalam mengembangkan usahanya, dengan tujuan untuk meningkatkan kehidupannya.

Schumpeter (2008) yang mengatakan bahwa jika suatu negara memiliki banyak entrepreneur, negara tersebut pertumbuhan ekonominya akan tinggi, yang sekaligus akan melahirkan pembangunan ekonomi yang tinggi pula. Jika suatu negara ingin maju, jumlah entrepreneur nya harus banyak. Kirzner, (1973) dalam bukunya "Competition and Entrepreneurship" mengatakan bahwa Enterprenuership is driving force behind economic growth. Dia juga mengatakan bahwa kewirausahaan merupakan bagian penting dalam pembangunan. Rasionalisasinya adalah jika seseorang memiliki kewirausahaan, dia akan memiliki karakteristik motivasi/mimpi yang tinggi (need of achievement), berani mencoba (risk taker), innovative dan independence. Dengan sifatnya ini, sedikit saja peluang dan kesempatan yang dimiliki, dia akan mampu merubah, menghasilkan sesuatu yang baru, relasi baru, akumulasi modal, baik berupa perbaikan usaha yang sudah ada (upgrading) maupun menghasilkan usaha baru. Dengan usaha ini, akan menggerakkan material/bahan baku untuk "berubah bentuk" yang lebih bernilai sehingga akhirnya konsumen mau membelinya. Pada proses ini akan terjadi pertukaran barang dan jasa, baik berupa sumber daya alam, uang, sumber daya sosial, kesempatan maupun sumber daya manusia. Dalam ilmu ekonomi, jika terjadi hal demikian, itu berarti ada pertumbuhan ekonomi, dan jika ada pertumbuhan ekonomi berarti ada pembangunan. Kajian teori ini senada dengan hasil penelitian di PKBM Cita Karya yang berlokasi di Kabupaten Klaten telah melakukan inovasi serta kreatifitas dalam pengembangan kewirausahaan, dari yang semula PKBM Cipta Karya yang hanya melakukan pembelajaran paket $\mathrm{A}, \mathrm{B}$, dan $\mathrm{C}$ sekarang telah melakukan pengembangan melalui kewirausahaan yang berbasis potensi lokal yaitu pembuatan jam tangan kayu. Hal ini yang sangat dibutuhkan oleh setiap negara termasuk Indonesia. Negara Indonesia dari total penduduk baru 1,6\% persen saja yang melakukan kewirausahaan dan itu masih jauh dari harapan sebuah negara, karena bila negara akan maju membutuhkan 2,5\% enterprenuership. Untuk mencapai $2,5 \%$ dari total penduduk yang menjalankan kegiatan kewirausahaan maka dibutuhkan pengembangan kewirausahaan agar negara ini mengalami pertumbuhan ekonomi. Hal ini terkait dengan temuan Subekti (2008) yang mengungkap adanya kelompok usaha ekonomi produktif sangat bermanfaat bagi masyarakat. Setelah mereka mengikuti kelompok usaha ekonomi tersebut, mereka mulai berkembang dan mampu meningkatkan pendapatan ekonominya. Sudjana (2000:263) mendefinisikan "Pembangunan masyarakat sebagai suatu gerakan yang direncanakan untuk menciptakan kondisi-kondisi bagi kemajuan sosial ekonomi masyarakat dengan partisipasi aktif dan kepercayaan sepenuh mungkin atas prakarsa masyarakat".

Hasil dari analisis teori serta hasil penelitian menunjukkan ada keselarasan yang dilakukan PKBM dalam mengembangkan kewirusahaan, dimana PKBM Cipta Karya telah mengembangkan usahanya dari pembelajaran paket $\mathrm{A}, \mathrm{B}$, dan $\mathrm{C}$ kemudian dikembangkan ke kewirausahaan dalam rangka pemberdayaan masyarakat melalui pembuatan jam tangan kayu yang berbasis potensi lokal. Proses pengembangan kewirausahaan pembuatan jam tangan kayu diawali dengan proses pelatihan, kemudian memproduksi dan dilanjutkan dengan pemasaran.

Sebagaimana yang dikemukakan oleh Defourny \& Nyssens (2010), empat kriteria yang mencerminkan dimensi ekonomi dan kewirausahaan sosial sebagai suatu perusahaan adalah: (1) kegiatan terus menerus memproduksi 
barang dan/atau jasa menjual, (2) tingkat otonomi yang tinggi, (3) tingkat risiko ekonomi yang signifikan, dan (4) jumlah pekerjaan yang dibayar secara minimum. Hasil penelitian yang telah dilakukan oleh Mungmachon (2012) tentang kearifan lokal, menyimpulkan masyarakat di Thailand mulai mempelajari secara kolektif masalah di masyarakat yaitu memulihkan kearifan lokal tradisional yang diintegrasikan dengan pengetahuan baru. Sedangkan di Rumania, menurut Dorobantu, Gheorghe, \& Nistoreanu (2012) dari hasil penelitiannya mengungkap orang-orang perdesaan menyadari bahwa mereka memiliki "harta karun" yaitu yang berupa masing-masing tradisi, lingkungan alam dan bagaimana mereka bekerja. Melalui pariwisata dengan bentuk geowisata, wisata budaya, agrowisata dan travelling dapat dipraktikkan dengan sukses di Rumania. Meski ada beberapa masyarakat lokal yang keterlibatannya rendah, tapi beberapa telah mampu mengembangkan kapitalisasi sumber daya dan mempromosikan desa wisata dengan mengadakan pameran nasional pariwisata perdesaan. Patarchanov (2012) hasil penelitiannya di Bulgaria di daerah pegunungan yang dijadikan sebagai pariwisata dipandang sebagai kegiatan yang kompleks. Hal itu melibatkan kegiatan tambahan seperti produksi, jasa, transportasi dan pendidikan. Pengembangan alternatif pariwisata di pegunungan memiliki peluang dalam pemecahan masalah di masyarakat seperti pengangguran, pendapatan rendah, ekonomi usaha yang sempit serta keterbelakangan dibandingkan dengan daerah dataran rendah dan kota-kota besar.

\section{Kendala Kewirausahaan melalui Pembuatan Jam Tangan Kayu}

Kendala yang dihadapai PKBM Cipta Karya adalah minimnya mesin produksi. Mesin produksi yang dimiliki sangat sedikit. Hal ini tidak sebanding dengan permintaan pasar dalam produk yang banyak, sehingga PKBM Cipta Karya belum bisa memenuhi kebutuhan pasar, baik dalam negeri maupun luar negeri. Selain itu para pekerja tidak bisa full time karena mereka sambil belajar kejar paket B maupun C. Warga belajar yang sedang mengikuti program kesetaraan kejar paket B (setara SMP) dan kejar paket C (setara SMA) sekaligus sebagai pekerja pembuat jam tangan. Oleh karenanya, waktu mereka digunakan untuk pembelajaran kejar paket sekaligus membuat jam tangan sebagai kegiatan kewirausahaan. Kondisi aktivitas pembelajaran di PKBM Cipta Ilmu ini dapat dikenal dengan istilah pembelajaran berbasis proyek. Sebagaimana gagasan John Dewey (Fakhruddin et al., 2012), pembelajaran berbasis proyek berasal dari konsep belajar sambil bekerja, yaitu proses perolehan hasil belajar dengan mengerjakan tindakan-tindakan tertentu sesuai tujuannya. Pendekatan pembelajaran berbasis proyek ini juga sebagaimana teori belajar konstruktivisme yang menekankan bahwa belajar tidak sekedar menghafal, akan tetapi membangun pengetahuan dan keterampilan baru melalui fakta-fakta yang dialami dalam kehidupannya.

Kendala dalam dua hal inilah yang dianggap menjadi kendala dalam proses produksi jam tangan kayu. Karena itu, jika pihak-pihak yang terkait seperti pemerintah, dapat membantu mengatasi kendala tersebut, misalnya dengan memberikan bantuan mesin/alat produksi. Kalaupun bantuan mesin produksi tidak dipenuhi, pemerintah dapat membantu PKBM Cipta Karya melalui pinjaman lunak dengan bunga rendah. Sehingga PKBM Cipta Karya dapat berkembang secara optimal. Seperti yang diungkap Fakhruddin et al. (2012:130), "Kendala utama yang dihadapi usaha kewirausahaan adalah menyangkut peralatan, modal, sarana penunjang kegiatan usaha".

Kendala dalam hal ini, pada dasarnya adalah terbatasnya modal usaha. Menurut Muarifuddin, Mulyono, \& Malik (2016), terbatasnya modal usaha itu justru semakin parah dengan terbatasnya akses pinjaman modal usaha. Pada tataran pengembangan pemasaran, modal sangat berguna sebagai tambahan meningkatkan produksi wirausaha. Tidak mudah mendapatkan pinjaman modal usaha yang terjangkau, artinya mendapatkan pinjaman 
dalam jumlah besar dengan angsuran ringan. Hal demikian pun diperkuat hasil penelitian Muarifuddin (2017) yang mengemukakan faktor penghambat internal dalam pengembangan usaha kewirausahaan desa wisata batik diantaranya yaitu kelemahan akses modal dalam jumlah besar. Para pengusaha batik dapat mengakses pinjaman modal usaha dalam jumlah besar, asal sebelumnya telah mendapatkan pinjaman dalam jumlah kecil secara berturutturut dapat dipercaya maka juga harus melewati pinjaman dalam jumlah yang bertahap. Meskipun pemerintah telah mengetahui kondisi tersebut, tidak banyak yang bisa dilakukan oleh pemerintah. Justru kehadiran pihak swasta yang lebih banyak memberikan fasilitas adanya aktivitas tersebut. Dukungan tokoh masyarakat sebagai motivator kelompok usaha sangat berperan penting dalam kesinambungan aktivitas kewirausahaan. Tentunya harapan besar untuk pemerintah mampu memfasilitasi sekaligus membina potensi daerah dalam mengembangkannya sebagai komoditas ekspor sekaligus sebagai komoditas wisata sehingga dapat bersinergi dengan hasil produksi lain yang saat ini telah berjalan. Seperti yang diungkap oleh Griffiths, Gundry, \& Kickul (2013), bahwa modal sosial dapat diakses oleh pengusaha sosial sebagai perangkat unik strategi untuk memobilisasi sumber daya yang dapat menghasilkan solusi nilai bagi masyarakat. Dikuatkan oleh Isife, Nnodim, \& Ochomma (2009), bahwa industri perdesaan sebagian besar masyarakat miskin terhambat oleh sumber daya keuangan, kurangnya insentif yang diberikan oleh mitra kerja sama, dan banyak bergantung kepada bantuan teknis.

\section{SIMPULAN}

Pengembangan kewirausahaan berbasis potensi lokal melalui pemberdayaan masyarakat melalui beberapa tahapan, yaitu pelatihan, produksi dan pemasaran. Kegiatan pelatihan, PKBM Cipta Karya telah melakukan pengembangan kewirausahaan berbasis potensi lokal, yaitu pembuatan jam tangan kayu, dalam proses pengembangannya diperlukan pelatihanpelatihan. Waktu pelatihan dilakukan selama 3 bulan hingga warga belajar mampu memproduksi jam tangan kayu. Proses produksi dilakukan setelah warga belajar paket B dan C menerima materi pembelajaran, khususnya tentang kewirausahaan pembuatan jam tangan kayu. Dalam produksi untuk 1 buah jam dihargai 200.000,- (dua ratus ribu rupiah). Pemasaran dilakukan melalui promosi di berbagai media, seperti brosur, media elektronik yaitu TV dan menggunakan media sosial seperti instagram, facebook dan lain-lain. Sedangkan untuk lokasi pemasaran adalah dalam negeri maupun luar negeri. Kendala yang dihadapi oleh PKBM adalah minimnya mesin produksi yang bersumber dari minimnya modal dan terbatasnya jam kerja warga belajar karena kegiatan utamanya mengikuti pembelajaran kejar paket, sehingga hasil produksi tidak bisa memenuhi kebutuhan pasar. Hal demikian dikenal dengan istilah permintaan/kebutuhan pasar lebih tinggi daripada penghasilan/produksi (demand lebih tinggi daripada supply).

Berkenaan dengan proses produksi yang tidak bisa memenuhi kebutuhan pasar, dikarenakan kurangnya mesin produksi, diharapkan pemerintah memberi bantuan lunak kepada lembaga yang membutuhkan. Hal demikian untuk meningkatkan produktifitas. Warga belajar kejar paket B dan C setelah lulus diharapkan tetap melanjutkan kewirausahaannya baik di PKBM Cipta Karya maupun di rumah masing-masing.

\section{DAFTAR PUSTAKA}

Adisasmita, R. (2006). Pembangunan pedesaan dan perkotaan. Yogyakarta: Graha Ilmu.

Agossou, V. (2000). Village participation in rural development. Benin: The Royal Tropical Institute or the World Bank.

Coombs, P. H., Prosser, R., \& Ahmed, M. (1973). New paths to learning for rural children and youth. New York: International Council for Educational Development (ICED).

Defourny, J., \& Nyssens, M. (2010). Conceptions of social enterprise and social entrepreneurship in europe and the united states: convergences and divergences. Journal of Social Entrepreneuship, 1(1), 3253. 
https://doi.org/http://doi.org/10.1080/1 9420670903442053

Dirdjojuwono, R. W. (2015). Membangun perdesaan modern. Bogor: PT Indec.

Dorobantu, M. R., Gheorghe, G., \& Nistoreanu, P. (2012). New ways to value tourism resources from rural environment. in competitiveness of agro economy. In Food and Environmental (pp. 385-394). Bucharest: Faculty of Agro-Food and Environmental Economics, University of Economic Studies. Retrieved from https://www.researchgate.net/publication /237148452_New_ways_to_value_touris $\mathrm{m} \_$resources_from_rural_environment

Esmailzade, A. (2013). Factor analysis of rural tourism development from villagers viewpoint in Chaharmahalva Bakhtiari Province (Case study: Yancheshmeh Village). International Journal of Agriculture and Crop Sciences, 21(5), 2630-2633.

Fakhruddin, Mulyono, S. E., Rifai, A., Utsman, \& Sutarto, J. (2012). Strategi pengembangan kewirausahaan masyarakat. Semarang: Widya Karya.

Griffiths, M. D., Gundry, L. K., \& Kickul, J. R. (2013). The socio-political, economic, and cultural determinants of social entrepreneurship activity: An Empirical examination. Journal of Small Business and Enterprise Development, 20(2), 341-357. https://doi.org/http://doi.org/10.1108/1 4626001311326761

Hadiyanti, P. (2006). Kemiskinan dan upaya pemberdayaan masyarakat. Komunitas, Jurnal Pengembangan Masyarakat Islam, 2(1), 33-46.

Harper, S. J. (1991). The political business cycle and fiscal policy in Canada. The University of Calgary.

Idris, N. A. (2003). Kemiskinan bandar dan sektor tidak formal di Malaysia. Universiti Kebangsaan Malaysia.

Isife, B. I., Nnodim, U. A., \& Ochomma, U. C. (2009). Constraints to government's capacity building programmes in rural communities of rivers state, Southern Nigeria. Journal of Social Science, 1(2), 2326.

Kaswan, \& Akhyadi, A. S. (2015). Social entrepreneurship (Mengubah masalah sosial menjadi peluang usaha). Bandung: Alfabeta.

Kavaliku, L. (2005). Culture and sustainable development in the Pacific. In Culture and Sustainable Development in The Pacific (In A. Hoop, p. 12). Canberra: Asia Pacific Press at The Australian National University.

Kemendiknas. (2010). Pengembangan pendidikan kewirausahaan. Jakarta: Badan Penelitian dan Pengembangan Kurikulum.

Kirzner, M. I. (1973). Competition and entrepreneurship. Chicago: University of Chicago Press.

Moleong, J. L. (2001). Metodologi Penelitian kualitatif. Bandung: PT. Remaja Rosdakarya.

Muarifuddin, M. (2017). Implementasi pembangunan desa wisata batik Desa Babagan Kecamatan Lasem Kabupaten Rembang. JPPM (Jurnal Pendidikan Dan Pemberdayaan Masyarakat), 4(1), 51-70.

Muarifuddin, M., Mulyono, S. E., \& Malik, A. (2016). Analisis kebutuhan pengembangan desa wisata batik Kecamatan Lasem Kabupaten Rembang. Journal of Nonformal Education, 2(1), 57-70.

Mungmachon, M. R. (2012). Knowledge and local wisdom: Community treasure. International Journal of Humanities and Social Science, 2(13), 174-181.

Nawawi, H. (2005). Metode penelitian bidang sosial. Yogyakarta: Gadjah Mada Press.

Patarchanov, P. (2012). Role and place of alternative tourism development in mountain areas. Journal of Settlements and Spatial Planning, 1(1), 149-155. Retrieved from http://jssp.reviste.ubbcluj.ro

Raharjo, T. J., Suminar, T., \& Muarifuddin, M. (2016). Peran pusat kegiatan belajar masyarakat dalam menanggulangi kemiskinan melalui pendidikan nonformal di Jawa Tengah. Journal of Nonformal Education, 2(1), 21-38.

Rifai, A. (2008). Pemberdayaan masyarakat melalui pendidikan nonformal. Semarang: Unnes Press.

Schumpeter, J. A. (2008). The theory of economic development: An inquiry into profits, capital, credit, interest and the business cycle. New Brunswick (U.S.A) and London (U.K.): Transaction Publishers.

Subekti, S. (2008). Pemberdayaan masyarakat miskin melalui kelompok usaha ekonomi produktif di Desa Tepusan Kecamatan Kaloran Kabupaten Temanggung. Universitas Negeri Yogyakarta.

Sudjana, D. (2000). Manajemen program pendidikan untuk pendidikan luar sekolah. Bandung: Falah Production.

Suryono, Y., \& Sumarno. (2013). Pembelajaran kewirausahaan masyarakat. Yogyakarta: Aditya Media.

Susilo, Y. S., \& Soeroso, A. (2014). Strategi pelestarian kebudayaan lokal dalam menghadapi globalisasi pariwisata: Kasus 
Kota Yogyakarta. Jurnal Penelitian BAPPEDA Kota Yogyakarta, 4, 3-11. Retrieved from www.jogja.go.id

Uemura, T. (2005). Sustainable rural development in Western Africa: The naam movement and the six "s." Western Africa: Sustainable development department (SD), food and agriculture organization of the united nations (FAO).

Retrieved from

http://www.fao.org/waicent/faoinfo/sust dev/ ROdirect/ROan0006.htm.

Usman, H. (2010). Manajemen: Teori, praktek, dan riset pendidikan. Jakarta: PT Bumi Aksara. 